\title{
DR. FRANJO KRMPOTIĆ - ZNAČAJNO IME GRADA SENJA I HRVATSKE MEDICINE
}

\author{
Maja Šojat-Bikić \\ Stare Gajnice 10 \\ HR 10090 Zagreb \\ msojatbikic@gmail.com
}

\author{
UDK: 61Krmpotić, F. \\ 94(497.5Senj)"20" \\ Pregledni članak \\ Ur.: 2021-04-19
}

Među značajne ličnosti koje su se rodile, školovale i mladenačke godine proživjele u gradu Senju nedvojbeno valja uvrstiti i primarijusa, docenta, dr. sc. Franju Krmpotića, specijalista ginekologije i porodništva, vrsnoga kliničara i pedagoga, čovjeka dojmljivih stručnih i znanstvenih postignuća, istinskog intelektualca širokih interesa i zadivljujuće memorije te nadasve domoljuba. Iako je većinu radnog vijeka proveo u Rijeci, do kraja života ostao je povezan s rodnim gradom i lokalnom zajednicom.

Franjo Krmpotić rođen je u Senju 5. srpnja 1929. U rodnom gradu završio je osnovnu školu i gimnaziju. Na Medicinski fakultet Sveučilišta u Zagrebu upisao se 1948. te diplomirao 1955. Kao liječnik pripravnik raspoređen je na rad u Općoj bolnici "Braća dr. Sobol" u Rijeci (1957. - 1958.). Potom dvije godine radi u Domu narodnog zdravlja Senj. Od 1964. do umirovljenja 1994. radi kao specijalist u Klinici za ginekologiju i porodništvo Opće bolnice "Braća dr. Sobol" u Rijeci (danas Klinički bolnički centar Rijeka). Bio je dragovoljac Domovinskog rata u Općoj bolnici Gospić te je 1995. odlikovan Spomenicom Domovinskog rata. Kao dugogodišnji član Senjskoga muzejskog društva i Kluba maturanata senjske gimnazije dao je značajan doprinos u životu lokalne zajednice. Preminuo je 4. prosinca 2020. u Rijeci.

Ovim se radom, utemeljenim ponajprije na istraživanju izvorne građe iz osobne arhive dr. Franje Krmpotića nastoji rekonstruirati njegov svrhovit i plodonosan život. U prilozima je dana bibliografija njegovih radova te popis sudjelovanja na kongresima i skupovima.

Ključne riječi: Franjo Krmpotić, liječnik, Senj, Rijeka, povijest medicine

\section{Uvod}

Život i djelo dr. Franje Krmpotića zaslužuju istraživanje koje nadilazi natuknice u periodici ${ }^{1}$ ili biografskim leksikonima poznatih osoba grada

\footnotetext{
${ }^{1}$ Usp. I.-B. PRPIĆ, 1989, 152.

${ }^{2}$ Usp. M. RAGUŽ, 2016, 94-95.
} 
Senja $^{2}$ i Novog Vinodolskog. ${ }^{3}$ Kroz nekoliko poglavlja nastoji se tematsko-kronološkim pristupom rasvijetliti gotovo četiri desetljeća (1956. - 1994.) njegova neumorna rada i kontinuiranog usavršavanja. $\mathrm{Za}$ stručno proučavanje djela $\mathrm{dr}$. Krmpotića trebalo bi specijalističko medicinsko znanje koje autorica teksta nema. Stoga je ovaj rad zamišljen kao pokušaj doprinosa zavičajnoj i hrvatskoj medicinskoj historiografiji. Iznesena faktografija, koja se temelji na proučavanju dokumenata ${ }^{4}$ (dopisi, odluke, potvrde, rješenja, svjedodžbe, ugovori, diplome, zahvalnice, fotografije i dr.), itekako svjedoči o značaju njegova doprinosa hrvatskoj medicinskoj misli. Na kraju je priložena bibliografija radova dr. Krmpotića te popis sudjelovanja na

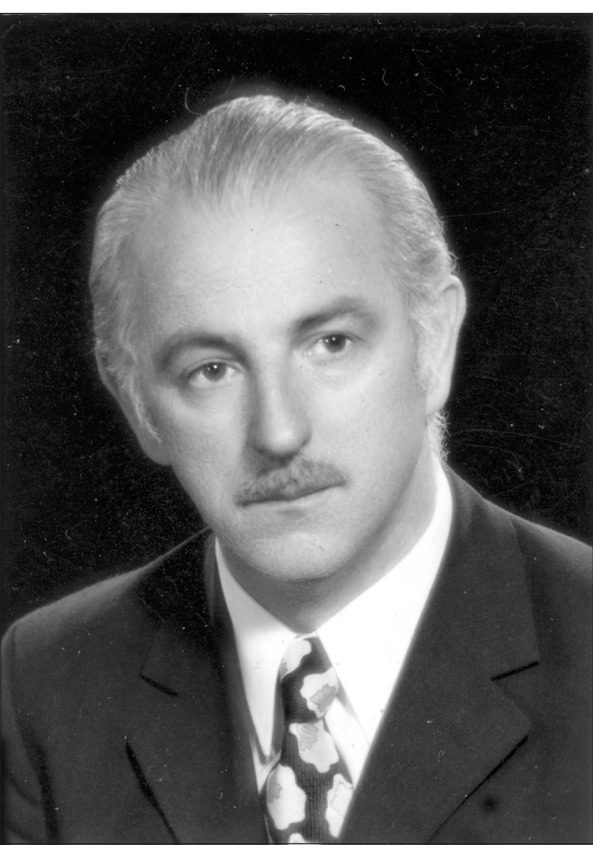

S1. 1. Dr. Franjo Krmpotić, Foto-Revija, Rijeka, 1974. kongresima i skupovima.

\section{Mladenačke godine i školovanje}

Franjo Krmpotić rođen je u Senju, 5. srpnja 1929., kao peto i posljednje dijete u trgovačkoj obitelji Marije, rođ. Lopac (1897. - 1968.) i Franje (1882. - 1938.). Obitelj je živjela u vlastitoj kući u Novakovoj 16.

Nakon suprugove prerane smrti majka Marija, žena poduzetna duha i dobrotvorka, uspješno je vodila trgovinu mješovite robe i skrbila ne samo o svojoj djeci već i o brojnim rođacima. Obitelj je osobito teško stradala u Drugome svjetskom ratu izgubivši dva sina, Vladimira i Milana, te stalni izvor prihoda kada joj je u poslijeratnoj nacionalizaciji oduzeta trgovina. Unatoč svim nedaćama Franjo je mladenačke godine proživio relativno bezbrižno i zaigrano, pod okriljem brižne majke i dviju sestara, Mirene i Zdenke. ${ }^{5}$

\footnotetext{
${ }^{3}$ Usp. K. ZORIČIĆ, 2020, 271.

${ }^{4}$ Slikovni prilozi korišteni u radu dio su osobne kolekcije dr. Franje Krmpotića (Klenovica).

${ }^{5}$ Zdenka Šojat, rođ. Krmpotić, majka je autorice ovog teksta.
} 


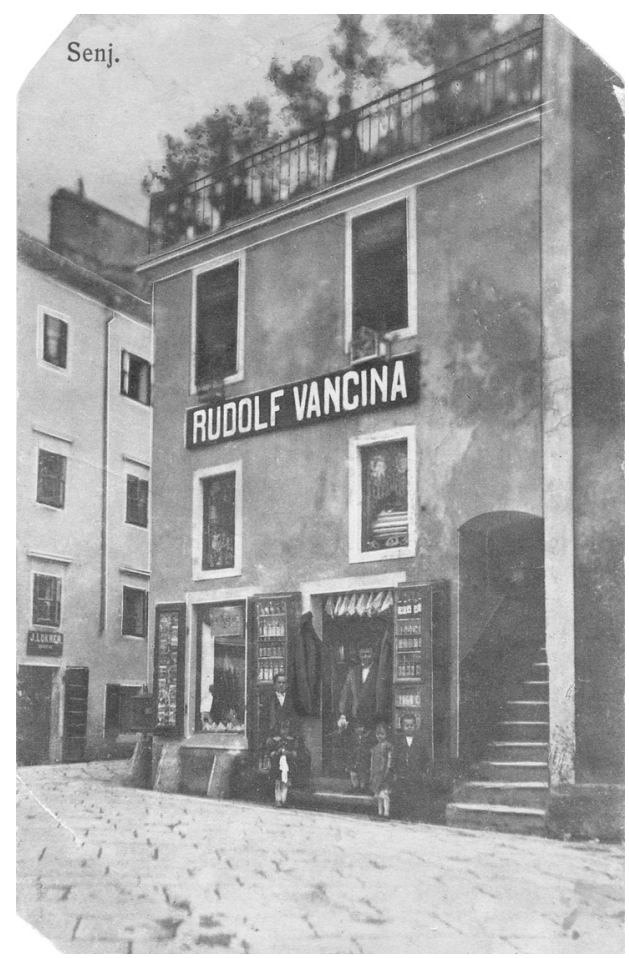

Sl. 2. Kuća Marije Krmpotić u Senju, razglednica tiskana u Beču, oko 1930.

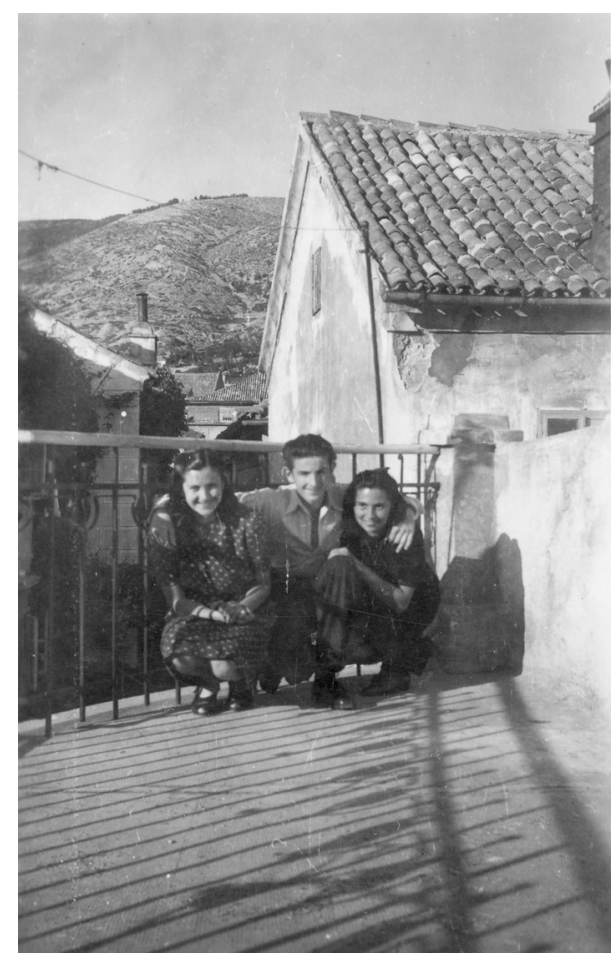

S1. 3. Mirena, Franjo i Zdenka Krmpotić na terasi obiteljske kuće

U rodnom gradu završio je pučku školu i gimnaziju. ${ }^{6}$ Ispit zrelosti položio je 11. lipnja 1948. Na Medicinski fakultet Sveučilišta u Zagrebu upisao se 20. rujna 1948. te diplomirao 29. prosinca 1955. "položivši sve stroge ispite". Svoje studentske dane nije posvetio samo učenju već i intenzivnom društvenom životu u senjskom krugu studenata u Zagrebu. O tome svjedoči i šaljiva diploma koju su mu po završetku studija darovali senjski studenti: "Rektorat Senjanov u Zagrebu izdaje na svitlo dana diplomu s kon se daje na znanje i ravnanje sviman, komen treba i ne treba, da je Frane Krmpotić - Franjić ovde dugo študiral na fakultetu na komen se uči za dohtura, dobro se učil, pa je bome danas u petak 13. I. 1956. i finil i zato mu se daje titula dohtur. Da je vo sve živa istina potvrđevaju..." (slijede potpisi senjskih studenata).

${ }^{6}$ Usp. B. DIKLIĆ, 1989, 97. 


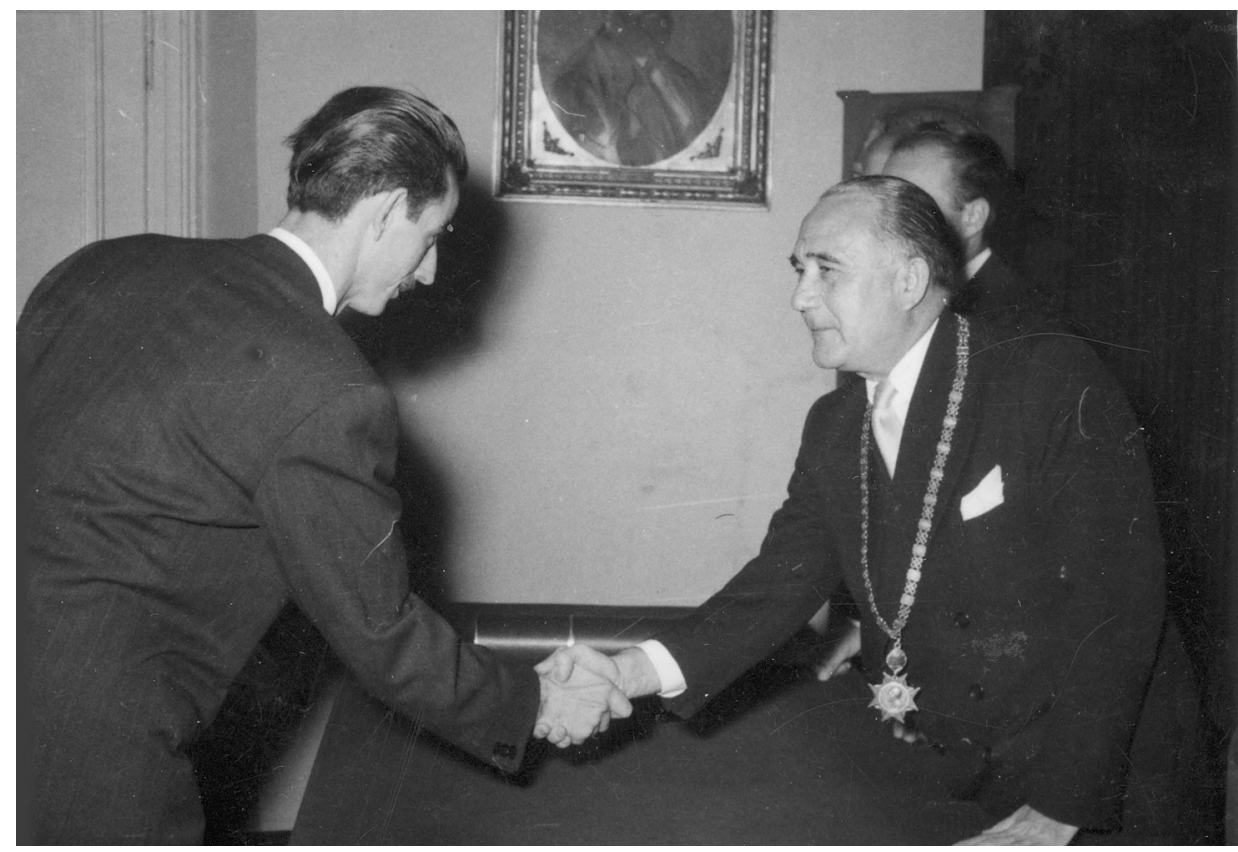

Sl. 4. Franjo Krmpotić prima diplomu doktora medicine, Zagreb, 31. prosinca 1955.

\section{Mladi liječnik}

Rješenjem sekretara Savjeta za narodno zdravlje i socijalnu politiku NRH od 7. ožujka 1956. "postavljen je za pripravnika zvanja liječnik i raspoređen na rad" u Općoj bolnici "Braća dr. Sobol", Rijeka. "Imenovani ima provesti na liječničkom pripravničkom stažu u ovoj bolnici vrijeme od 1. VII. 1957. do zaključno 23. III. 1958."

Dana 1. veljače 1958. premješten je u Zdravstveni centar Senj. ${ }^{7}$ U stalnu službu primljen je 23. ožujka 1958. Uvjerenjem Narodnog odbora općine Senj i Doma narodnog zdravlja Senj od 22. veljače 1960. "uredovno se potvrđuje da je Krmpotić dr. Franjo bio na dužnosti kod ove ustanove od 1. II. 1958. do 30. IX. 1959." U tom razdoblju obavljao je i dužnost upravnika Zdravstvene stanice u Jurjevu.

U želji za stručnim usavršavanjem podnosi molbu za premještaj u Rijeku, na radno mjesto liječnika - nastavnika Primaljske škole. ${ }^{8}$ Školski odbor pozitivno

${ }^{7}$ U međuvremenu, od 1. lipnja 1956. do 15. svibnja 1957., regulirao je vojnu obvezu kao polaznik Škole za rezervne sanitetske oficire pri Vojno-medicinskoj akademiji u Beogradu (1. lipnja - 30. rujna 1956.) te kao garnizonski liječnik u Šibeniku. 


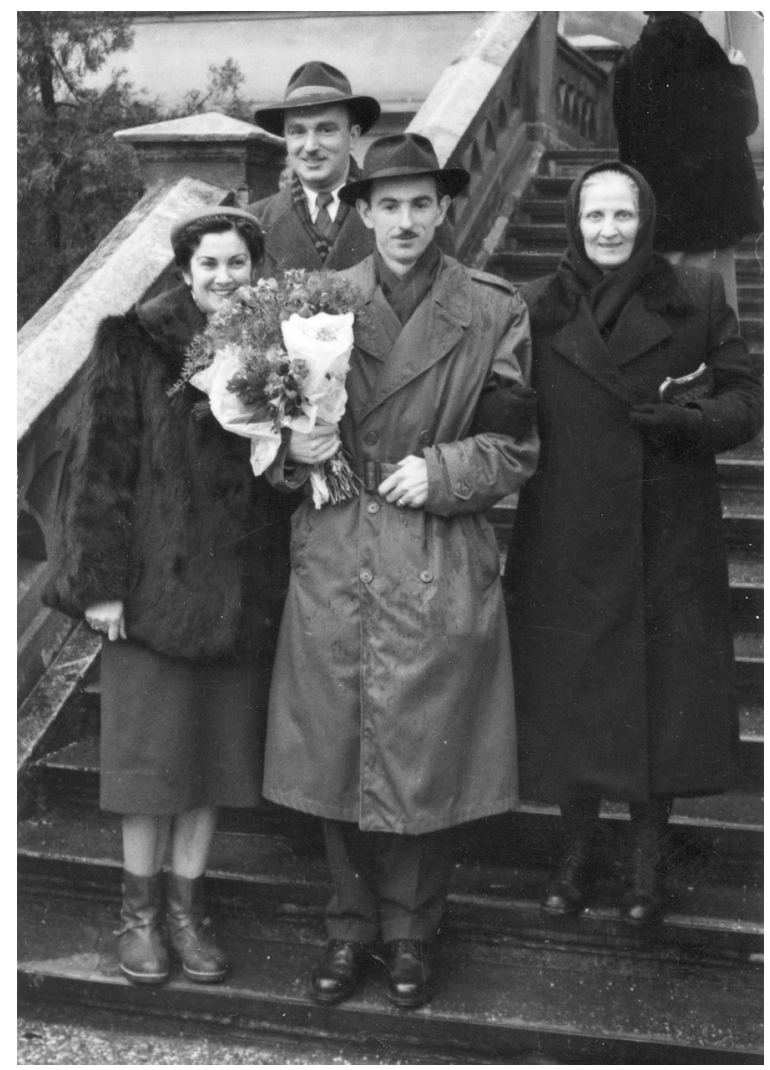

Sl. 5. Promocija doktora medicine; slijeva nadesno sestra Mirena Pavelić, šogor Juraj Pavelić, dr. Franjo

Krmpotić i majka Marija Krmpotić, Zagreb, 31. prosinca 1955. rješava molbu te tadašnji direktor škole, prim. dr. Drago Vrbanić, dopisom s datumom 5. kolovoza 1959. javlja dr. Krmpotiću da je mjesto liječnika slobodno od 1. rujna savjetujući "da odmah pošaljete propisnu molbu, opširnu biografiju i suglasnost ustanove gdje ste zaposleni da pristaje na Vaš premještaj u Primaljsku školu na Rijeci". Rješenjem Narodnog odbora kotara Rijeka, Sekretarijata za opću upravu - Odsjeka za službenička pitanja od 25. rujna 1959. dr. Krmpotić je "primljen u službu Primaljske škole u Rijeci i postavljen za nastavnika za praktičan rad u zvanju liječnik I. vrste". U školi predaje predmet Zaštita majke $i$ djece. Stručni ispit položio je 21. ožujka 1960. Zajedno s dr. Miljenkom Flajšmanom asistirao je prof. dr. Dragi Vrbaniću u pisanju tada prijeko potrebnog stručnog udžbenika za primalje. ${ }^{9}$

Odlukom Školskog odbora Primaljske škole od 1. rujna 1962., "s obzirom na značaj poslova, stručnost i rezultate koje je pokazao u radu", dr. Krmpotić napreduje na položaj profesora za praktičnu nastavu za porodništvo i ginekologiju. Od 1. lipnja 1962. do 1. lipnja 1963. obnašao je i dužnost upravitelja Doma Primaljske škole brinući se za smještaj učenica.

\footnotetext{
${ }^{8}$ Prva javna primaljska škola u Hrvatskoj osnovana je 1786. upravo u Rijeci. Usp. V. UREMOVIĆ, 2006, 87.

${ }^{9}$ Usp. V. UREMOVIĆ - L. MIROŠEVIĆ - I. VUKELIĆ, 2014, 55.
} 


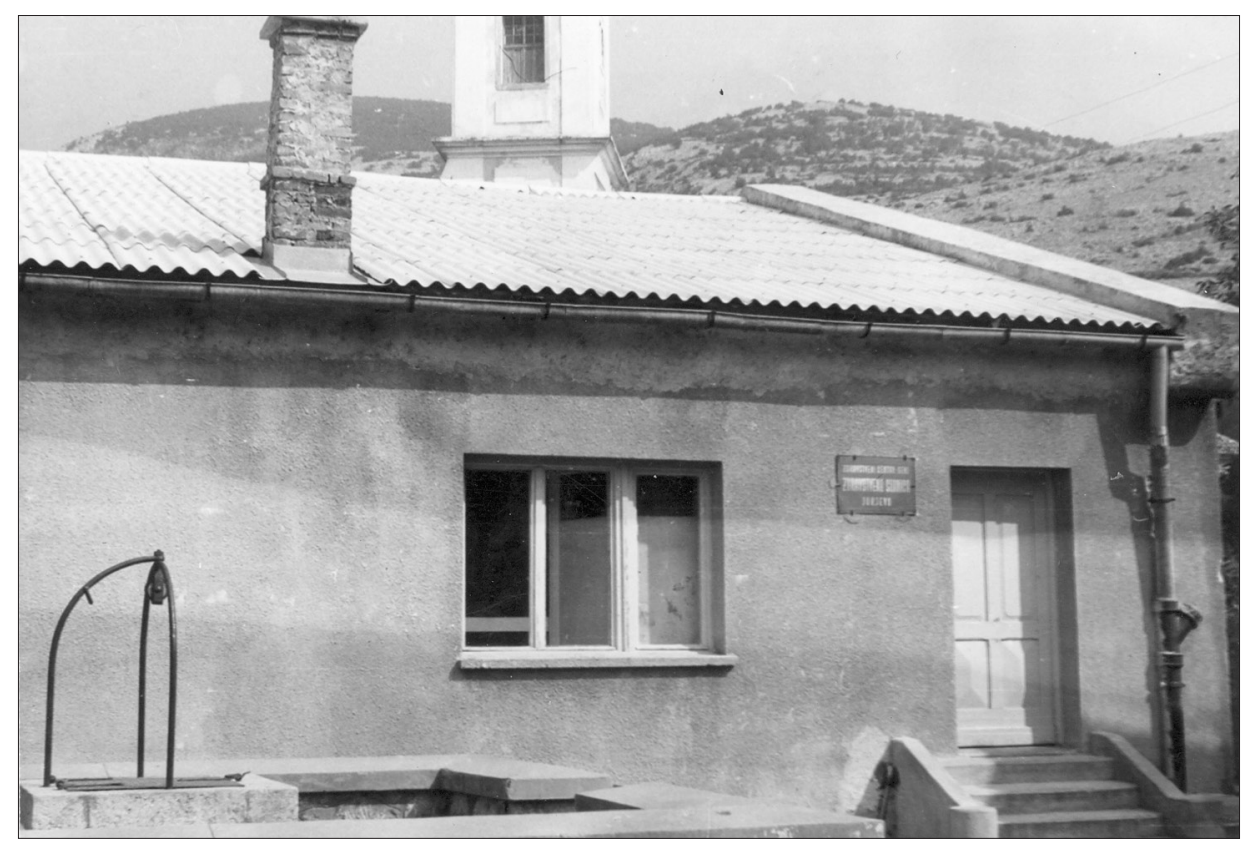

Sl. 6. Zdravstvena stanica u Sv. Jurju, 1958./59.

\section{Tri desetljeća kliničkog rada i stalnog usavršavanja}

Po dolasku u Rijeku, 1. listopada 1959., dr. Krmpotić započinje specijalizaciju na Ginekološko-porođajnom odjelu Opće bolnice "Braća dr. Sobol". ${ }^{10}$ Već kao specijalizant pohađa tečaj iz kolposkopije u Kliničkoj bolnici za porodništvo i ženske bolesti u Ljubljani, 15. travnja - 15. svibnja 1960. Uskoro kolposkopija postaje rutinska pretraga u cilju ranog otkrivanja raka vrata maternice, a svoja iskustva dr. Krmpotić objavljuje u stručnoj periodici. ${ }^{11}$ Specijalistički ispit položio je u Ljubljani, 23. travnja 1964.

Sporazumom o zasnivanju radnog odnosa na neodređeno vrijeme od 1. srpnja 1964. primljen je na radno mjesto liječnika specijalista Ginekološkoporođajnog odjela Opće bolnice "Braća dr. Sobol" i tako započinje jedna iznimna 30-godišnja karijera liječnika - kliničara i znanstvenika.

${ }^{10}$ Bolnica je poslije Drugoga svjetskog rata nekoliko puta mijenjala naziv, od Opće bolnice "Braća dr. Sobol" (sljednice Gradske bolnice Sv. Duha), Kliničke bolnice "Braća dr. Sobol" (1975.), Bolničkog centra Rijeka (1982.) do današnjeg naziva Klinički bolnički centar Rijeka (1984.). Godine 1976. Ginekološko-porođajni odjel stječe status Klinike za ginekologiju i porodništvo.

${ }^{11}$ Usp. J. GOBIĆ, 2010, 82. 


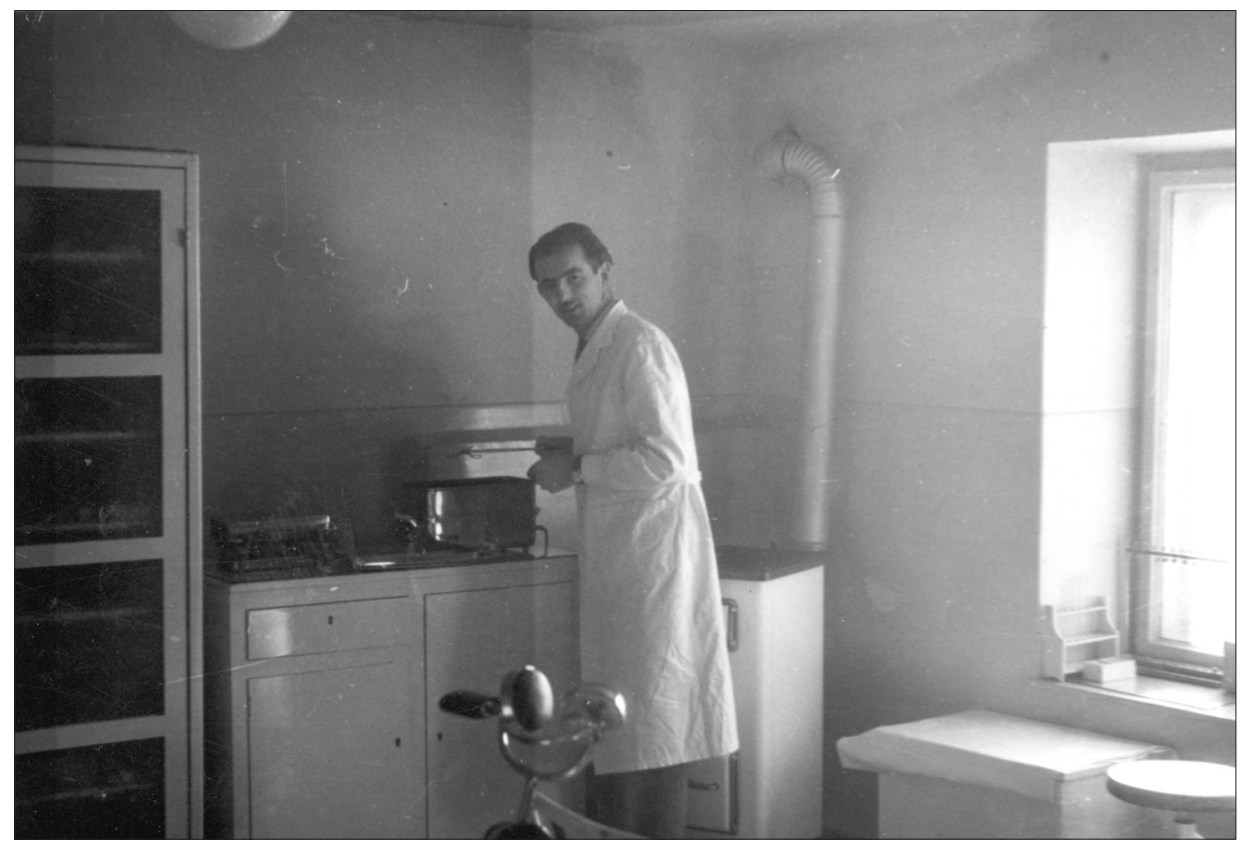

S1. 7. Mladi liječnik Franjo Krmpotić, Sv. Juraj, 1958./59.

Ubrzano napreduje pa je već 12. travnja 1966. izabran za člana Savjeta Opće bolnice "Braća dr. Sobol". Kontinuirano se educira i usvaja nove medicinske tehnike. Tečaj iz primjene hipnoze u medicini završio je u Bolnici za ginekologiju i porodništvo u Kranju, 17. - 18. prosinca 1971., a intenzivni tečaj iz operacijske ginekologije u Klinici za ginekologiju i porodništvo Sveučilišta u Ljubljani, 10. -14. veljače 1975. Sedamdesetih se godina počinju izvoditi korektivne operacije na jajovodima u svrhu liječenja steriliteta. Upravo dr. Krmpotić ima posebne zasluge za uvođenje mikrokirurških operacija u riječku ginekološku praksu. ${ }^{12}$

Doktorsku disertaciju pod naslovom Acido-bazno stanje krvi majke $i$ ploda tokom poroda vođenog $u$ hipnozi obranio je na Medicinskom fakultetu Sveučilišta u Rijeci, 9. srpnja 1976., pred povjerenstvom koje su činili prof. dr. Drago Vrbanić (mentor i predsjednik povjerenstva), prof. dr. Davor Perović, doc. dr. Daniel Rukavina i prof. dr. Slobodan Ćuk. Naslov primarijusa stekao je 10. veljače 1977. odlukom Komisije za priznavanje naziva primarius Republičkog sekretarijata za narodno zdravlje i socijalnu zaštitu SRH.

${ }^{12}$ Ibid., 83. 


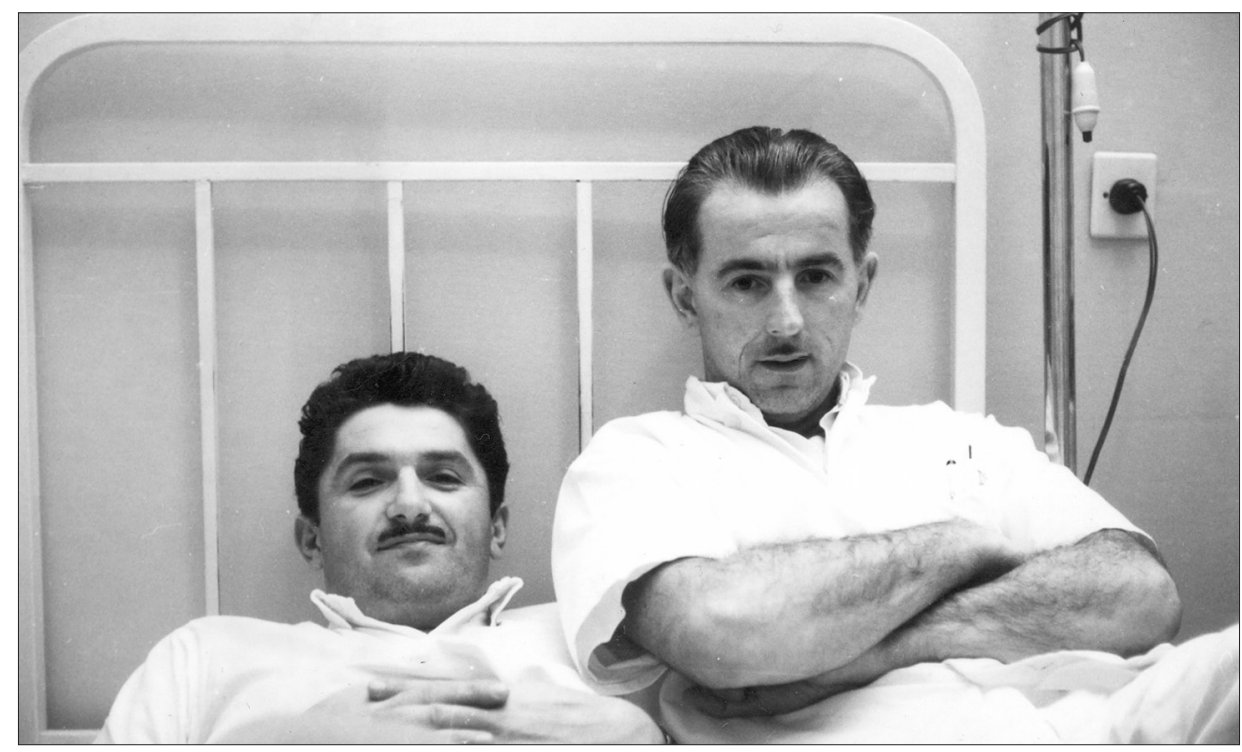

S1. 8. Dr. Miljenko Flajšman i dr. Franjo Krmpotić na dežurstvu u Ginekološko-porođajnom odjelu Opće bolnice "Braća dr. Sobol", Rijeka, oko 1965.

Od 17. veljače 1977. do 18. prosinca 1978. obnaša dužnost pomoćnika ravnatelja bolnice za medicinske poslove. Odlukom Radničkog savjeta Komisije za radne odnose od 20. srpnja 1978. raspoređen je na radno mjesto šefa Operacijskog odjela Klinike za ginekologiju i porode, počevši od 1. siječnja 1979. Iako opterećen rukovoditeljskim poslovima, dr. Krmpotić nastavlja stručno usavršavanje pa tako u Ginekološkoj klinici Kliničkog centra Ljubljana pohađa tečaj iz ginekološke endoskopije, 31. ožujka - 5. travnja 1980. Odlukom Radničkog savjeta Bolničkog centra Rijeka od 6. travnja 1982. raspoređen je na radno mjesto šefa Operacijskog odjela, a 5. listopada 1983. izabran je za rukovoditelja Radne jedinice Kirurške djelatnosti II. Rješenjem Radničkog savjeta KBC-a Rijeka od 2. srpnja 1987. "raspoređen je na poslove i radne zadatke vršitelja dužnosti pomoćnika predstojnika Klinike za ginekologiju i porode". Dužnost pomoćnika predstojnika obnaša od 11. listopada 1989. do 1. siječnja 1994.

Umirovljen je 10. srpnja 1994. Iako je mogao još raditi, prevagnula je želja za mirnim životom u kući uz more. ${ }^{13}$

${ }^{13}$ Dr. Krmpotić je od 25. svibnja 1982. bio u sretnom braku s Ivanom, rođ. Bujan, koja je nažalost prerano preminula 23. veljače 1999. 


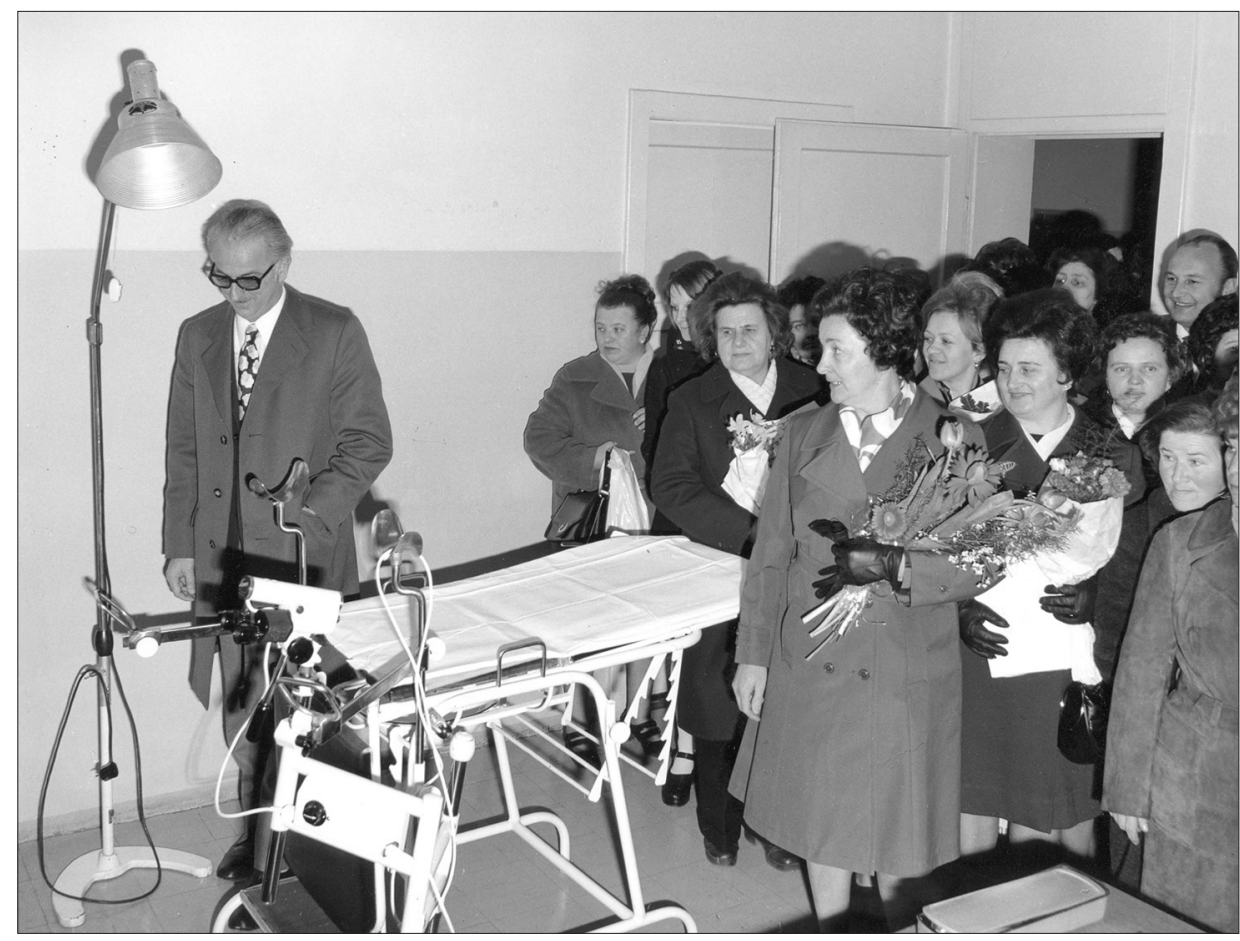

S1. 9. Dr. Franjo Krmpotić s djelatnicama "3. maja", Foto Belveder Žorž, Rijeka, 1977.

\section{Dopunska izvanbolnička djelatnost}

Dr. Krmpotić je povremeno radio u riječkim domovima zdravlja dajući i na taj način svoj doprinos širenju zdravstvene kulture i brizi za zdravlje žena. Prema Ugovoru o djelu sklopljenim 6. travnja 1977. s RZ "Zajednički poslovi" ZROBI "3. maj" obavlja sistematsko-ginekološke preglede žena.

Dana 1. lipnja 1982. OOUR "Solidarnost" ugovara s njim ginekološki pregled svojih radnica. S Domom zdravlja Rijeka zasniva 1. ožujka 1983. "radni odnos u dopunskom radu" (ugovor je produljen 12. ožujka 1984.). Odlukom RZ "Zajednički poslovi" u sastavu RO "Brodomaterijal" od 27. veljače 1989. odobreno je zaključivanje ugovora s dr. Krmpotićem "o povremenom-privremenom obavljanju poslova" u Zdravstvenoj stanici RO "Brodomaterijal". ${ }^{14}$ Rješenjem Predsjedništva Okružnog suda u Rijeci od

${ }^{14}$ Značenje kratica: OOUR - Osnovna organizacija udruženog rada, RO - Radna organizacija, RZ - Radna zajednica, ZROBI - Zajednica radnih organizacija brodograđevne industrije. 
23. siječnja 1978. "imenovan je za vrijeme od četiri godine stalnim sudskim vještakom liječničke struke - za ginekologiju kod Okružnog i Općinskog suda u Rijeci". Iz dokumenata u osobnoj arhivi dr. Krmpotića razvidno je da je tu dužnost obavljao u dva mandata, do 1986.

\section{Znanstvenik i pedagog}

Kao autor i suautor dr. Krmpotić objavljuje stručne i znanstvene članke u domaćoj i inozemnoj periodici te zbornicima radova. Sudjeluje na brojnim kongresima i skupovima u zemlji i inozemstvu (Dubrovnik, Opatija, Poreč, Rijeka, Zagreb, Dobrna, Beograd, Novi Sad, Sombor, Herceg-Novi, Ohrid, Sarajevo, Budimpešta, München, Poznanj, Russe i dr.). Zanimala ga je i povijest naše medicine pa se bavio istraživanjem života i djela značajnih liječnika poput dr. Eme Pavleković ${ }^{15}$ i dr. Viktora Finderlea. ${ }^{16}$

Svoje bogato znanje i kliničko iskustvo prenosio je liječnicima specijalizantima i srednjoškolskim učenicima. Uz njega je stasao velik broj specijalista ginekologa te naraštaji zdravstvenih djelatnika srednje stručne spreme. Gotovo dva desetljeća, do 1975., predavao je u Školi za medicinske sestre (primaljski i opći smjer) i Školi za zdravstvene tehničare.

U Registar istraživača Republičkog komiteta za znanost, tehnologiju i informatiku SRH upisan je 31. siječnja 1990. kao "znanstvenik suradnik u znanstvenom području medicina pod matičnim brojem 169375". Odlukom Savjeta Medicinskog fakulteta Sveučilišta u Rijeci od 11. srpnja 1990. izabran je u "znanstveno-nastavno zvanje docenta za predmet Ginekologija i opstetricija s kumulativnim radnim vremenom počevši od 1. listopada 1990." U fakultetskoj nastavi sudjeluje do 5. srpnja 1994.

\section{Članstvo u stručnim udrugama}

Skupina intelektualaca osnovala je 29. svibnja 1966. u Rijeci Znanstveno društvo za povijest zdravstvene kulture kao ogranak Naučnog društva za

15 Izlaganje na stručnom sastanku Naučnog društva za historiju zdravstvene kulture Jugoslavije - Ogranak Rijeka, u Senju, 21. lipnja 1974. Rad je objavljen u Senjskom zborniku, 6, 1975.

${ }^{16}$ Izlaganje na Skupu posvećenom 90. obljetnici rođenja doc. dr. Viktora Finderlea i 40. obljetnici objave ideje o uvođenju vakuum ekstraktora za dovršenje porođaja, Opatija, 24. listopada 1992. Neobjavljeni rukopis Viktor Finderle - život i djelo u osobnom arhivu dr. Franje Krmpotića. 


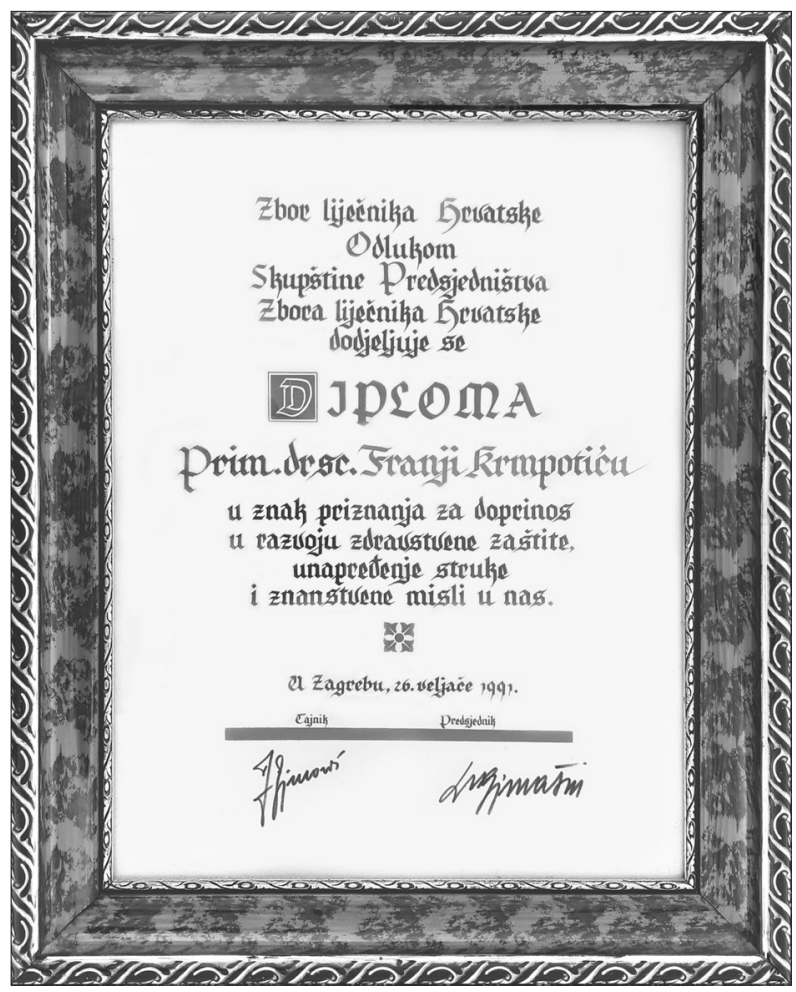

S1. 10. Diploma Zbora liječnika Hrvatske dodijeljena prim. dr. sc. Franji Krmpotiću, Zagreb, 26. veljače 1991.

historiju zdravstvene kulture Jugoslavije. ${ }^{17}$ Dr. Krmpotić bio je član i jedno vrijeme predsjednik tog ogranka. ${ }^{18}$

Aktivno je sudjelovao u radu Zbora liječnika Hrvatske (ZLH, danas Hrvatski liječnički zbor). Bio je izabran i za predsjednika Ginekološke sekcije ZLH-a - Ogranak Rijeka te delegata u upravi Sekcije u Zagrebu. Na tematskim sastancima Sekcije održao je niz predavanja. Od 1964. bio je član Udruženja ginekologa-opstetričara Jugoslavije (UGOJ) te član Fédération internationale de gynécologie et d'obstétrique sa sjedištem u Ženevi.

${ }^{17}$ Usp. A. ŠKROBONJA - I. SALOPEK, 2017, 12.

${ }^{18}$ Dr. Krmpotić je bio predsjednik Organizacijskog odbora te glavni i odgovorni urednik Zbornika radova 26. sastanka Naučnog društva za historiju zdravstvene kulture Jugoslavije (Poreč, 30. IX.-2. X. 1976.), Znanstveno društvo za povijest zdravstvene kulture - Rijeka, Rijeka, 1978. 


\section{Nagrade i priznanja}

Odlikovan je Ordenom zasluga za narod sa srebrnom zvijezdom, 7. studenoga 1986. U listopadu 1988. primio je zahvalnicu Udruženja ginekologaopstetričara Jugoslavije u znak priznanja za suradnju i pomoć u radu UGOJ-a. Odlukom Skupštine predsjedništva Zbora liječnika Hrvatske dodijeljena mu je diploma "u znak priznanja za doprinos u razvoju zdravstvene zaštite, unapređenja struke i znanstvene misli u nas", 26. veljače 1991.

\section{Domoljub}

Iako je već bio zašao u sedmo desetljeće života, dr. Krmpotić je svoje stručno znanje stavio na raspolaganje ratom ugroženoj domovini. Rješenjem o imenovanju ratnih zapovjednika i njihovih ratnih zamjenika klinika i zavoda KBC-a Rijeka od 7. studenoga 1991. imenovan je ratnim zamjenikom. Pridružio se medicinskom osoblju Opće bolnice u Gospiću i nekoliko mjeseci radio u podrumskom prostoru bolnice. ${ }^{19}$

Odlukom Skupštine Hrvatskoga liječničkog zbora-Ogranka Rijeka od 12. prosinca 1992. dodijeljeno mu je priznanje za izniman doprinos u Domovinskom ratu. Kako piše na poleđini članske iskaznice Udruge hrvatskih dragovoljaca Domovinskog rata s nadnevkom učlanjenja 6. siječnja 1994., dr. Krmpotić se "dragovoljno odazvao pozivu domovine braniti svoj dom". Odlukom tadašnjeg predsjednika Republike Hrvatske dr. Franje Tuđmana odlikovan je Spomenicom Domovinskog rata, 19. svibnja 1995.

\section{Djelovanje u lokalnoj zajednici i umirovljenički dani}

Dr. Franjo Krmpotić bio je čovjek širokih interesa koji nadilaze strogo stručno medicinsko područje. Tako se 1963. učlanio u Klub kulturnih radnika Rijeke.

Bio je i dugogodišnji član Senjskoga muzejskog društva, njegov predsjednik u razdoblju 1995. - 1996. ${ }^{20}$ te član uredničkog kolegija 22. i 23. sveska Senjskog zbornika. ${ }^{21}$ Prema riječima Melanije Prpić, tajnice Gradskog

${ }^{19}$ Godine 1991. bolnicu napušta većina medicinskog osoblja srpske nacionalnosti pa je rat dočekala s malim brojem liječnika i drugog zdravstvenog osoblja. Ne smije se zaboraviti kako je pored vukovarske bolnice upravo Opća bolnica Gospić pretrpjela najveća razaranja u Domovinskom ratu. Veliku pomoć u tim izvanrednim i ratnim uvjetima pružio je KBC Rijeka.

${ }^{20}$ Usp. B. LJUBOVIĆ, 2009, 14-15.

${ }^{21}$ Ibid., 18. 


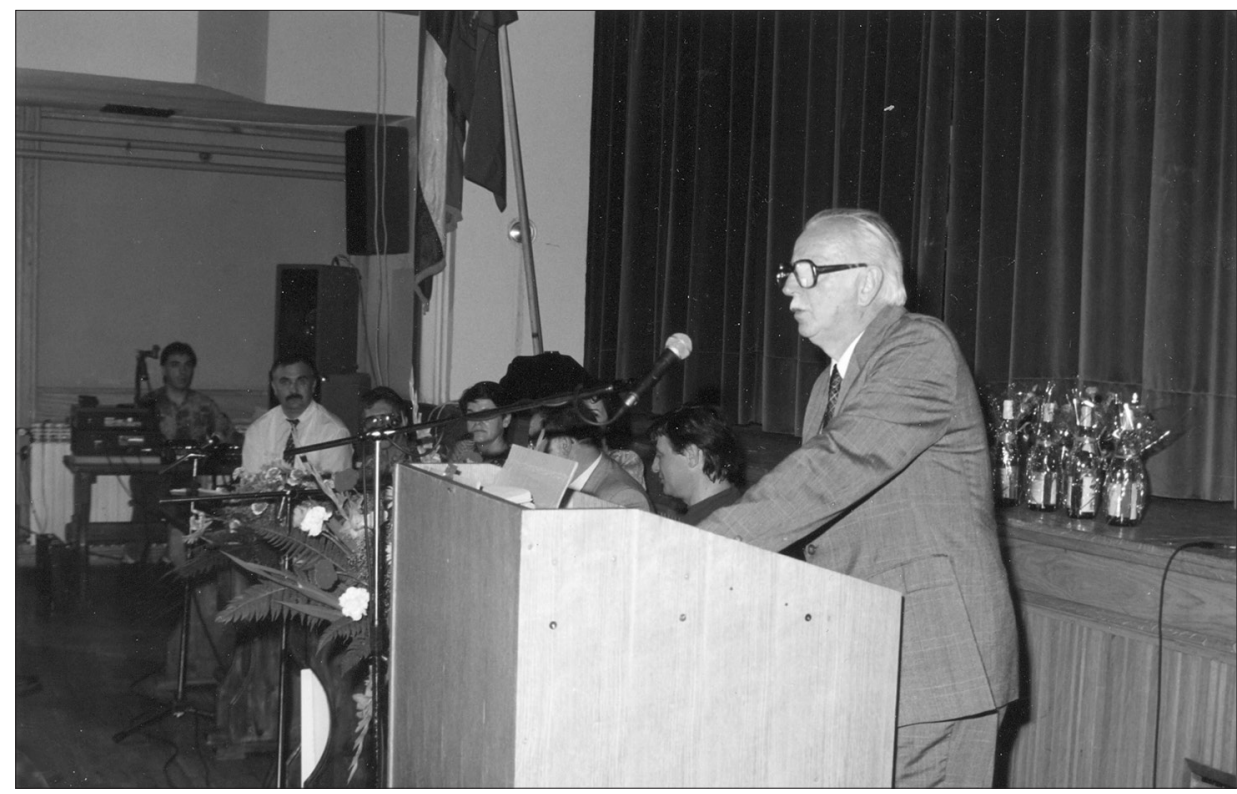

Sl. 11. Dr. Franjo Krmpotić na Danu maturanata senjske gimnazije, Senj, 25. lipnja 1994.

muzeja Senj, arhiv Senjskoga muzejskog društva vrlo je skroman te nema podatka kada se dr. Krmpotić učlanio u Društvo. "Jedino se sa sigurnošću, iz dostupnih zapisnika, može potvrditi da je bio predsjednik u razdoblju od 1. travnja 1995. do 25 . rujna 1997. godine."22

Nije zanemariva ni njegova aktivnost u Klubu maturanata senjske gimnazije.

Dragocjene podatke dao je Branko Svast, tajnik Kluba: "Vaš ujak g. Franjo Krmpotić bio je član Kluba maturanata senjske gimnazije od 20. lipnja 1981. (godinu dana nakon što je osnovan). Bio je jedan od najaktivnijih članova. Uistinu, ‘živa arhiva'. Kad god bi negdje zapeli, on bi nam detaljno i točno sve objasnio. Ne odnosi se to samo na Klub, već na primjer i na nogomet. Ako je na starijim fotografijama trebalo dešifrirati likove, on bi to bez problema i pogreške učinio. Jako je volio Senj i gotovo do posljednjih dana je u njega dolazio." ${ }^{23} \mathrm{Rad}$ Kluba je i novčano podupirao. Stoga ga je Upravni odbor Kluba, postupajući prema odredbama Statuta (čl. 7) i statutarnoj odluci, na sjednici održanoj 15. studenoga 1996. imenovao članom donatorom.

${ }^{22}$ Elektronička poruka Melanije Prpić, 26. ožujka 2021.

${ }^{23}$ Elektronička poruka Branka Svasta, 25. ožujka 2021. 


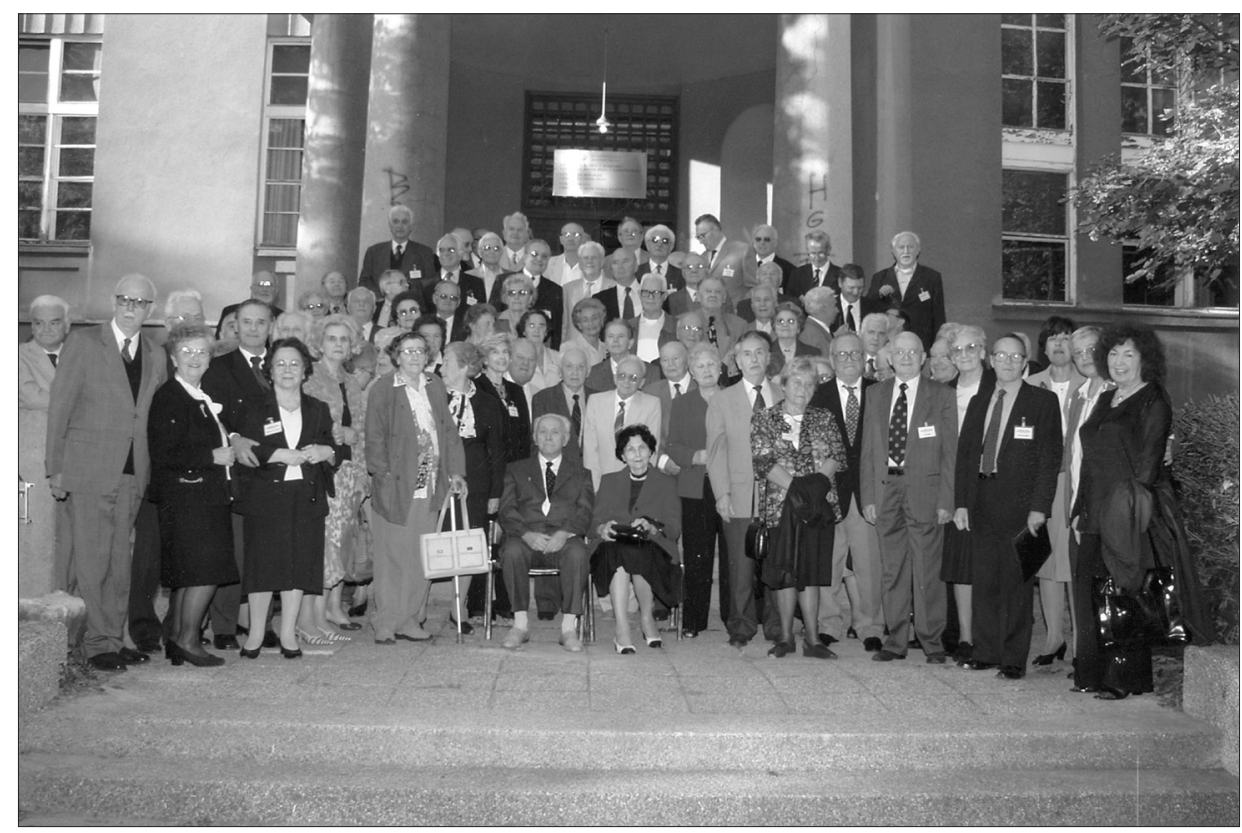

Sl. 12. Bivši studenti medicine na proslavi 55. obljetnice upisa na Medicinski fakultet u Zagrebu, dr. Franjo Krmpotić prvi slijeva u prvom redu, Zagreb, 26. rujna 2003.

Senjska liga protiv raka, na prvoj sjednici predsjedništva održanoj 2. listopada 2003., imenovala je dr. Krmpotića počasnim članom.

Svoje umirovljeničke godine proživio je u pitoresknoj Klenovici, okružen knjigama, u blizini voljenog Senja kamo je redovito odlazio na kapučino ("kod Tome") i druženje sa Senjanima. O njegovoj vitalnosti svjedoči i činjenica da je bio jedan od rijetkih bivših studenata iz generacije 1948./49. koji se odazvao pozivu na svečano obilježavanje šezdeset pete ${ }^{24}$ i sedamdesete obljetnice ${ }^{25}$ upisa na Medicinski fakultet Sveučilišta u Zagrebu. ${ }^{26}$

Preminuo je u KBC-u Rijeka, 4. prosinca 2020. Sahranjen je 9. prosinca na Gradskom groblju sv. Vid u Senju. U sjećanju ljudi koji su ga poznavali ili bili njegovi pacijenti ostat će upamćen kao pristupačan "čovjek iz naroda" unatoč

${ }^{24}$ Usp. V. BAKAŠUN, 2013, 67.

${ }^{25}$ Usp. V. BAKAŠUN, 2019, 47.

${ }^{26}$ Ova se generacija prvi put sastala 1978. na proslavi tridesete obljetnice upisa. Otada se redovito sastajala u zgradi Dekanata Medicinskog fakulteta na Šalati, svakih pet godina zadnjeg petka u mjesecu rujnu. 
zavidnim postignućima, "lokalpatriot", vozač Mazde i u 91. godini života, elokventan, druželjubiv i nadasve pristojan gospodin.

\section{Zaključak}

Dr. Franjo Krmpotić pripada krugu riječkih liječnika druge polovice 20. stoljeća koji su ostavili dubok trag u organiziranju i razvoju bolničkog zdravstva te posljedično tomu i unapređivanju života grada.

Iznimnim zalaganjem i radom obilježio je razvoj i napredovanje ginekološko-opstetričke struke te postigao rezultate prepoznate u stručnim i znanstvenim krugovima i izvan Rijeke. Osobito je značajan njegov doprinos primjeni hipnoze u porođaju. O tome svjedoče dokumenti iz njegove osobne arhive, objavljeni radovi, sudjelovanja na kongresima i skupovima te dodijeljena mu priznanja.

Ljubav prema moru i rodnom kraju zadržala ga je u Rijeci iako su mu se nudile i druge mogućnosti, kako u zemlji tako i u inozemstvu. Grad Senj može se podičiti brojnim zaslužnim zavičajnicima među kojima istaknuto mjesto pripada i dr. Franji Krmpotiću čije ime ostaje trajno upisano u povijesti hrvatske medicine.

\section{Literatura}

\section{Izvori}

Osobni arhiv dr. Franje Krmpotića, Klenovica

\section{Knjige i članci}

Vjekoslav BAKAŠUN, Bivši studenti medicine proslavili 65 godina od upisa, Liječničke novine, 123, Zagreb, 2013.

Vjekoslav BAKAS̆UN, Dočekali smo i proslavili 70 godina od upisa na MEF u Zagrebu, Liječničke novine, 176, Zagreb, 2019.

Bogdan DIKLIĆ, Nastavnici učenici, maturanti i direktori senjske gimnazije i COUO "Vladimir Čopić" od 1839-1989 godine, Senjski zbornik, 16, Senj, 1989, 71-110.

Jasna GOBIĆ, Riječko rodilište: povijest bolničke ginekologije i porodništva u Rijeci 1946. - 1985., Chamango, Rijeka, 2010.

Blaženka LJUBOVIĆ, Obilježavanje 60. godišnjice djelovanja Senjskog muzejskog društva, Senjski zbornik, 36, Senj, 2009, 5-20. 
Ivanka-Branka PRPIĆ, Učenici i maturanti senjske gimnazije koji su postigli znatne uspjehe na znanstvenom, kulturnom, društvenom i sportskom polju, Senjski zbornik, 16, Senj, 1989, 141-162.

Mirko RAGUŽ, Leksikon poznatih Senjana, Senjsko muzejsko društvo - Ogranak Matice hrvatske Senj, Senj, 2016.

Ante ŠKROBONJA - Igor SALOPEK, U prigodi pedesete obljetnice djelovanja Hrvatskoga znanstvenog društva za povijest zdravstvene kulture, Acta medicohistorica Adriatica, 15 (Suppl. 1), Rijeka, 2017, 11-18.

Vladimir UREMOVIĆ, Razvoj primaljskog školstva u Rijeci, Acta medico-historica Adriatica, 4 (1), Rijeka, 2006, 85-96.

Vladimir UREMOVIĆ - Lovro MIROŠEVIĆ - Ivan VUKELIĆ, Razvoj primaljskog školstva u Rijeci, Primaljski vjesnik, 16, Zagreb, svibanj 2014, 52-56.

Krsto ZORIČIĆ, Grad Novi Vinodolski: Prilozi za biografski leksikon, Grad Novi Vinodolski - Narodna čitaonica i knjižnica - Naklada Kvarner, Novi Vinodolski, 2020 .

\section{Bibliografija radova dr. Franje Krmpotića}

Miljenko FLAJŠMAN - Franjo KRMPOTIĆ - Branko VOLARIĆ, Sudsko-medicinski aspekt iznenadne smrti u trudnoći i porodu, Zbornik radova Šestog kongresa ginekologa-opstetričara Jugoslavije u Zagrebu, 10. - 12. X. 1968., Drugi svezak, Organizacioni odbor VI. kongresa ginekologa-opstetričara Jugoslavije, Zagreb, 1968, 299-302.

Franjo KRMPOTIĆ, $\mathrm{Ca}$ in situ u našem materijalu, Zbornik ginekoloških sekcija Slovenskog zdravniškog društva i Zbora liječnika Hrvatske u Dobrni, 25., 26. i 27. maja 1962., Slovensko zdravniško društvo - Ginekološka sekcija, Ljubljana, 1962, 13-15.

Franjo KRMPOTIĆ - Miljenko FLAJŠMAN, Operativno liječenje spontanih pobačaja i naša iskustva, Medicina, 2 (2), Rijeka, 1965, 157-163.

Franjo KRMPOTIĆ - Vladimir UREMOVIĆ - Ivan KIRINČIĆ - Aleksandra FRKOVIĆ, Desetogodišnje iskustvo $\mathrm{u}$ prekidanju odmakle trudnoće intraamnijalnom instilacijom otopina soli, Zbornik radova Prvog jugoslovenskog simpoziuma o aktuelnim problemima u fertilitetu i sterilitetu, Udruženje ginekologa-opstetričara Jugoslavije - Sekcija za sterilitet i fertilitet, Ohrid, 1971, 271-275.

Franjo KRMPOTIĆ, Vođenje poroda u hipnozi, Medicina, 9 (4), Rijeka, 1972, 429-434.

Franjo KRMPOTIĆ, Dr. Ema Pavleković - značajno ime u povijesti hrvatske medicine, Senjski zbornik, 6, Senj, 1975, 373-376.

Franjo KRMPOTIĆ, Acido-bazno stanje krvi majke i ploda tokom poroda vođenog $u$ hipnozi, doktorska disertacija, Sveučilište u Rijeci - Medicinski fakultet, Rijeka, ožujak 1976. 
Franjo KRMPOTIĆ, Fetalna oksigenacija za vrijeme porođaja u hipnozi, Perinatalni dani 1976: Zbornik radova V godišnjeg sastanka Sekcije za perinatalnu medicinu Zbora liječnika Hrvatske, Zbor liječnika Hrvatske - Sekcija za perinatalnu medicinu, Zagreb, 1977, 577-582.

Franjo KRMPOTIĆ, The elimination of hyperventilation in childbirth by the use of hypnosis, Proceedings of the $2^{\text {nd }}$ European Congress of Hypnosis in Psychotherapy and Psychosomatic Medicine, Slovenian Society for Clinical and Experimental Hypnosis, Dubrovnik, 1980, 181-185.

Franjo KRMPOTIĆ, Disanje u porođaju i njegov utjecaj na acidobazno stanje krvi majke i ploda, Acta Facultatis medicae Fluminensis, 10 (3-4), Rijeka, 1985, 46-48.

Franjo KRMPOTIĆ, Udruženost genitalne endometrioze i mioma uterusa u operiranih bolesnica, Zbornik radova VIII. intersekcijskog sastanka Ginekološko-akušerske sekcije Srpskog lekarskog društva i Sekcije ginekologa Zbora liječnika Hrvatske, Teme: preeklampsije i eklampsije, endometrioze, Sombor, 1985, 110-113.

Franjo KRMPOTIĆ - Nikola MATEJČIĆ, Carski rez u Klinici za ginekologiju i porodništvo Rijeka u razdoblju od godine 1965. do 1984., Acta Facultatis medicae Fluminensis, 10 (3-4), Rijeka, 1985, 49-51.

Franjo KRMPOTIĆ, Genitalna endometrioza udružena s miomom uterusa, Medicina, 22 (1), Rijeka, 1986, 35-36.

Franjo KRMPOTIĆ, Tri raznovrsna i istodobna tumora na ženskim genitalnim organima, Acta Facultatis medicae Fluminensis, 11 (1-2), Rijeka, 1986, 54-55.

Franjo KRMPOTIĆ - Stanko RUPČIĆ, Ginekološke operacije u starijoj životnoj dobi, Medicina, 22, Rijeka, 1986, 159-161.

Franjo KRMPOTIĆ, Svjetska slava Malmströmu, Novi list, god. 88, br. 289, Rijeka, 12. i 13. prosinca 1987., 13.

Franjo KRMPOTIĆ - Snježana STANKOVIĆ - Mladen ŽENTIL - Gordana OLUIĆ, Utjecaj disanja na acidobazno stanje krvi rodilje, Zbornik sažetaka XIII. perinatalnih dana, Zagreb, 1988, 50-51.

Franjo KRMPOTIĆ - Nikola MATEJČIĆ, Brief an die Schriftleitung zur Arbeit MengMei Liu und F. K. Beller: Ist eine Rotation bei der Vakuumextraktion möglich?, Geburtshilfe und Frauenheilkunde, 49, Stuttgart - New York, 1989, 73-74.

Franjo KRMPOTIĆ - Nikola MATEJČIĆ, The elimination of maternal hypocapnia in childbirth by use of deep slow breathing, Acta Facultatis medicae Fluminensis, 14 (1-2), Rijeka, 1989, 27-29.

Franjo KRMPOTIĆ -Nikola MATEJČIĆ, The influence of maternal deep slow respiration of the values of $\mathrm{pH}$ fetal scalp blood, Acta Facultatis medicae Fluminensis, 14 (1-2), Rijeka, 1989, 31-33.

A. LEOVIĆ - I. VUKOJA - Franjo KRMPOTIĆ - Miljenko FLAJŠMAN, Pravni položaj fetusa, Zbornik sažetaka III. regionalnog simpozija o sudsko-medicinskim aktuelnostima, Opatija, 17. do 19. X. 1969., Zavod za sudsku medicinu Medicinskog fakulteta u Rijeci, Rijeka, 1969. 
Vladimira SEIDEL-MARČEC - Vladimir UREMOVIĆ - Franjo KRMPOTIĆ, Idiopatska trombopenička purpura i trudnoća, Medicinski glasnik, 21 (3-4), Beograd, 1967, 70-72.

Nikola MATEJČIĆ - Franjo KRMPOTIĆ - Stanko RUPČIĆ, Disgerminom ovarija, Acta Facultatis medicae Fluminensis, 11 (1-2), Rijeka, 1986, 51-53.

Nikola MATEJČIĆ - Franjo KRMPOTIĆ, Eksplorativna kiretaža prilikom konizacije vrata maternice, Medicina, 23, Rijeka, 1987, 151-152.

Nikola MATEJČIĆ - Daniel RUKAVINA - Franjo KRMPOTIĆ, Immunologic reactivity of new-borns in pregnancies with EPH gestosis, Acta Facultatis medicae Fluminensis, 16 (1-2), Rijeka, 1991, 27-33.

Nikola MATEJČIĆ - Daniel RUKAVINA - Franjo KRMPOTIĆ, Role of immunological factors in aetiopathogenesis of EPH gestosis, Acta Facultatis medicae Fluminensis, 18 (1), Rijeka, 1993, 47-53.

Radojka SAMARŽIJA - Mile STAMENKOVIĆ - Henrik BOSNER - Franjo KRMPOTIĆ, Perinatalni mortalitet djece niske porođajne mase rođene u stavu zatkom, Zbornik sažetaka XIII. perinatalnih dana, Zagreb, 1988, 138.

Vladimir UREMOVIĆ - Franjo KRMPOTIĆ, Neki epidemiološki aspekti pobačaja na Rijeci, Obavještenja: higijena, epidemiologija, zdravstveno prosvjećivanje, 5 (4), Rijeka, 1962, 305-316.

Vladimir UREMOVIĆ - Franjo KRMPOTIĆ, Naših 100 konizacija, Ginekologija i opstetricija, 3 (3-4), Zagreb, 1963, 93-99.

Vladimir UREMOVIĆ - Savo VLAŠIĆ - Milan SRKETIĆ - Franjo KRMPOTIĆ, Epidemiološko-socijalni aspekt pobačaja na području Rijeka - Pula, Zbornik radova V. kongresa ginekologa-opstetričara Jugoslavije, Sarajevo, 1964, 281286.

Vladimir UREMOVIĆ - Savo VLAŠIĆ - Franjo KRMPOTIĆ, Neke demografske osobitosti riječkog područja, Medicina, 8 (2-3), Rijeka, 1971, 626-632.

Drago VRBANIĆ - Vladimir UREMOVIĆ - Franjo KRMPOTIĆ, Atipični oblik interseksualizma s mozaičkim kariotipom XY / XO / XX, Jugoslavenska ginekologija i opstetricija, 15, Zagreb, 1975, 123-128.

Vjekoslav WELTRUSKY - Franjo KRMPOTIĆ, Die hormonale Therapie der Endometriosis mit Orgametril, Congressus Danubiensis Secundus Gynaecologorum cum participatione internationali, Abstracts, Budimpešta, 1972, 72.

Popis sudjelovanja dr. Franje Krmpotića na kongresima i skupovima ${ }^{27}$

II. intersekcijski sastanak ginekoloških sekcija Slovenskog zdravniškog društva i Zbora liječnika Hrvatske, Dobrna, 25. - 27. svibnja 1962. (Ca in situ u našem materijalu)

${ }^{27} \mathrm{U}$ zagradama je naveden naslov izlaganja. 
V. kongres ginekologa-opstetričara Jugoslavije, Sarajevo, 1964. (Epidemiološkosocijalni aspekt pobačaja na području Rijeka - Pula)

VI. kongres ginekologa-opstetričara Jugoslavije, Zagreb, 10. - 12. listopada 1968. (Sudsko-medicinski aspekt iznenadne smrti u trudnoći i porodu)

III. regionalni simpozij o sudsko-medicinskim aktuelnostima, Opatija - Rijeka, 17. - 19. listopada 1969. (Pravni položaj fetusa)

I. jugoslovenski simpozium o aktuelnim problemima u fertilitetu i sterilitetu, Ohrid, 4. - 6. lipnja 1971. (Desetogodišnje iskustvo u prekidanju odmakle trudnoće intraamnijalnom instilacijom otopina soli)

Congressus Danubiensis Secundus Gynaecologorum cum participatione internationali, Budimpešta, 6. - 8. lipnja 1972. (Die hormonale Therapie der Endometriosis mit Orgametril)

XXVI. sastanak Naučnog društva za historiju zdravstvene kulture Jugoslavije, Poreč, 30. rujna - 2. listopada $1976 .^{28}$

V. perinatalni dani, Zagreb, 15. - 18. prosinca 1976. (Fetalna oksigenacija za vrijeme porođaja u hipnozi)

XXIX. naučni sastanak: Zdravstvena kultura Beograda kroz vekove, Beograd, 7. - 8. prosinca 1979.

$2^{\text {nd }}$ European Congress of Hypnosis in Psychotherapy and Psychosomatic Medicine, Dubrovnik, 12. - 18. svibnja 1980. (The elimination of hyperventilation in childbirth by the use of hypnosis)

XXI Zjazd Naukowy Polskiego Towarzystwa Ginekologicznego, Poznanj, 27. - 30. rujna 1981.

Die 44. Tagung der Deutschen Gesellschaft für Gynäkologie und Geburtshilfe, München, 13. - 17. rujna 1982.

X. kongres ginekologa-opstetričara Jugoslavije, Herceg-Novi, 11. - 13. listopada 1984.

VIII. intersekcijski sastanak Ginekološko-akušerske sekcije Srpskog lekarskog društva i Sekcije ginekologa Zbora liječnika Hrvatske, Sombor, 10. - 11. svibnja 1985. (Udruženost genitalne endometrioze i mioma uterusa u operiranih bolesnica)

Kongres ginekologa podunavskih zemalja, Russe, 18. - 20. listopada 1985. (Udruženost theca-staničnog tumora ovarija s karcinomom endometrija i miomom uterusa)

XII. perinatalni dani, Zagreb, 16. - 18. travnja 1986. (Rizični faktori za pojavu endometritisa kod carskog reza)

International Symposium on in vitro Fertilization and Embryo Transfer, Dubrovnik, 7. - 10. listopada 1986.

XIII. perinatalni dani, Zagreb, 11. - 13. svibnja 1988. (Utjecaj disanja na acidobazno stanje krvi rodilje; Perinatalni mortalitet djece niske porođajne mase rođene $u$ stavu zatkom)

${ }^{28}$ Dr. Krmpotić bio je predsjednik Organizacijskog odbora te glavni i odgovorni urednik Zbornika radova. 
XI. kongres ginekologa-opstetričara Jugoslavije, Novi Sad, 4. - 7. listopada 1988. (Uloga disanja rodilje u suvremenom vođenju porođaja)

Skup posvećen 90. obljetnici rođenja doc. dr. Viktora Finderlea i 40. obljetnici objave ideje o uvođenju vakuum ekstraktora za dovršenje porođaja, Opatija, 24. listopada 1992. (Doc. dr. Viktor Finderle - život i djelo)

\section{DR FRANJO KRMPOTIĆ - A SIGNIFICANT NAME OF THE TOWN OF SENJ AND CROATIAN MEDICINE}

\section{Summary}

Amongst the significant personalities who were born, educated and spent their youth in the town of Senj, it is undoubtedly worth mentioning the chief doctor, assistant professor, Franjo Krmpotić Ph.D, a specialist in gynaecology and obstetrics, an excellent clinician and pedagogue, a man of impressive professional and scientific achievements, a true intellectual of wide interests and an amazing memory, and above all a patriot. Although he spent most of his working life in Rijeka, he remained connected to his hometown and the local community for the rest of his life.

Franjo Krmpotić was born in Senj on $5^{\text {th }}$ July 1929 . He finished primary school and secondary school in his hometown. He enrolled at the Medical Faculty of the University of Zagreb in 1948 and graduated in 1955. As a trainee doctor, he was assigned to work at the Braća dr. Sobol General Hospital in Rijeka (1957-1958). He then worked for two years at the Public Health Centre in Senj. From 1964, until his retirement in 1994, he worked as a specialist at the Clinic for Gynaecology and Obstetrics of the Braća dr. Sobol General Hospital in Rijeka (today the Clinical Hospital Centre Rijeka). He was a Homeland War volunteer at the Gospić General Hospital and in 1995 he was awarded the Homeland War Memorial Medal. As a longstanding member of the Senj Museum Association and the Senj Secondary School Graduates Club, he made a significant contribution to the life of the local community. He died on $4^{\text {th }}$ December 2020 in Rijeka.

This work, based primarily on the research of the original material from the personal archive of Dr Franjo Krmpotić, attempts to reconstruct his purposeful and fruitful life. Attached are the bibliography of his works and the list of his participation at congresses and meetings.

Keywords: Franjo Krmpotić, physician, Senj, Rijeka, history of medicine 